\title{
Differences in MMP-2 Expression in High- and Low-Grade MPNST and its Correlation with Prognostic Factors
}

Perbedaan Ekspresi MMP-2 pada MPNST Derajat Tinggi dan Rendah serta Hubungannya dengan Faktor Prognostik

\author{
Niniek Hardini ${ }^{1 *}$, Nurjati Chairani Siregar ${ }^{2}$, Puspita Eka Wuyung ${ }^{2}$ \\ ${ }_{1}^{1}$ Department of Anatomical Pathology, Faculty of Medicine, Universitas Pembangunan Nasional Veteran Jakarta \\ 2 Department of Anatomical Pathology, Faculty of Medicine, Universitas Indonesia
}

DATA OF ARTICLE:

Received: 16 Jan 2021

Reviewed: 15 Mar 2021

Revised: 01 July 2021

Accepted: 08 July 2021

\section{*CORRESPONDENCE:}

ninieksabar@gmail.com

DOI:

10.18196/mmjkk.v21i2.10882

TYPE OF ARTICLE:

Research

\begin{abstract}
Malignant peripheral nerve sheath tumor (MPNST) is a soft tissue sarcoma, which is difficult to distinguish from other spindle cell sarcomas. MPNST is hostile, with a high recurrence, and tends to metastasize hematogenously, especially to the lungs. A phase of the metastasis is a degradation of the extracellular matrix, where Matrix Metalloproteinase (MMP) plays an essential role in this process. Gelatinasetype MMP, MMP-2 and MMP-9, can degrade basal membrane and fibrillar collagen to open the invasion pathway. MMP-2 can degrade more collagen and non-collagen extracellular matrix than MMP-9. Therefore, the study aimed to see the relationship between MMP-2 overexpression and histopathological malignancy grading and other clinical prognostic variables. The study was conducted by immunohistochemical staining of MMP-2 in 39 cases, consisting of 19 cases of low-grade MPNST and 20 cases of high-grade MPNST. Subsequently, an analysis of the relationship between MMP-2 overexpression and the malignancy grading and clinical variables was performed, such as age, sex, and tumor size and location. MMP-2 overexpression was seen in 19 (95\%) cases of high grade and three (15.8\%) cases of low-grade MPNST (p 0.000). The study also found a significant relationship between MMP-2 overexpression and histopathology grading, which may be helpful to define the prognosis.
\end{abstract}

Keywords: MMP-2; low-grade MPNST and high-grade MPNST; prognostic factors

\begin{abstract}
Abstrak: Malignant peripheral nerve sheath tumor (MPNST) adalah sarkoma jaringan lunak yang sulit dibedakan dengan jenis sarkoma sel epitel spindel lainnya. MPNST bersifat agresif dengan angka rekurensi yang tinggi dan cenderung bermetastasis terutama ke paru. Salah satu tahap metastasis dengan cara mendegradasi matriks ekstraseluler dimana Matrix Metalloproteinase (MMP) berperan penting dalam proses ini. MMP tipe gelatinase yaitu MMP2 dan MMP-9 memiliki kemampuan dalam mendegradasi membran basal dan kolagen fibrillar sehingga dapat membuka jalur invasi. MMP-2 mampu mendegradasi lebih banyak matriks ekstraseluler kolagen dan non kolagen dibandingkan MMP-9. Penelitian bertujuan menilai hubungan antara peningkatan ekspresi MMP-2 dengan derajat keganasan histologik dan variabel prognostik klinis lainnya. Penelitian dilakukan dengan pulasan imunohistokimia MMP-2 pada 39 kasus yang terdiri atas 19 kasus MPNST derajat rendah dan 20 kasus MPNST derajat tinggi. Selanjutnya analisis hubungan antara peningkatan ekspresi MMP-2 dengan derajat keganasan dan variabel klinis seperti usia, jenis kelamin, ukuran dan lokasi tumor. Peningkatan ekspresi MMP-2 ditemukan pada 19 (95\%) kasus MPNST derajat tinggi dan $3(15,8 \%)$ kasus MPNST derajat rendah (p 0,000). Penelitian ini menemukan hubungan yang kuat antara peningkatan ekspresi MMP-2 dengan derajat keganasan MPNST. Peningkatan ekspresi MMP-2 sejalan dengan peningkatan derajat histologik, sehingga dapat digunakan dalam menilai progresivitas MPNST.
\end{abstract}

Kata Kunci: Protein MMP-2; MPNST derajat tinggi dan MPNST derajat rendah; faktor prognostik 


\section{INTRODUCTION}

Malignant Peripheral Nerve Sheath Tumor (MPNST) is an ectomesenchymal tumor that is difficult to diagnose because of its identical morphology to other spindle cell sarcoma. ${ }^{1}$ The diagnosis of soft tissue tumor refers to the grading system of the French Federation of Cancer Centre against Cancers (FNCLCC), while histological type alludes to WHO soft tissue and musculoskeletal. The prominent role in determining tumor grading is to measure the possibility of distant metastasis, which correlates with the patient's prognosis. ${ }^{1,2}$

MPNST has a poor prognosis and is one of the most aggressive sarcomas, with a high recurrence rate and a tendency to metastasize to the lungs. ${ }^{3}$ In this regard, Matrix Metalloproteinase (MMP) takes an important role in matrix degradation and contributes to tumor invasion and metastasis. Many types of MMP, namely gelatinase types such as MMP-2 and MMP-9, are essential for the development of malignant tumors. ${ }^{4,5}$ Gelatinase is the main enzyme to degrade the basal membrane and fibrillar collagen to pave the way for cell invasion..$^{6-8}$ MMP-2 can degrade type I-IV collagen and extracellular matrix (ECM) non-collagen compared to MMP-9 that cannot degrade type I-III collagen and ECM non-collagen. In addition, metastasis of malignant cells produces a large amount of MMP-2 by stimulating the surrounding stromal cells to produce MMP-2. MMP-2 overexpression can be found in cell migration, invasion, and metastasis. ${ }^{9}$

Moreover, MMP inhibitors can impede MMP activity, especially MMP-2 activity, in tumor growth and spread. One of the MMP inhibitors that can be used as a potential target of cancer therapy is batimastat. Batimastat is a synthetic MMP inhibitor that functions as an antineoplastic and antiangiogenic. ${ }^{9}$ Besides, MMP inhibitors can be a potential therapy in several pathological conditions, including inflammatory processes and cancer. ${ }^{10}$

Research conducted by carrying out Matrix Metalloproteinase-2 for MPNST cases was first performed at the Anatomical Pathology Laboratory, Faculty of Medicine, University of Indonesia, Cipto Mangunkusumo Hospital Jakarta. It is expected that MMP-2 can be used as a prognostic factor for MPNST progression and provide hope for a new treatment method in cases where total resection is not possible by providing an additional therapy in the form of targeted therapy. ${ }^{10}$ Targeted therapy works by preventing extracellular matrix damage caused by MMP-2. ${ }^{11}$ Thus, this research assessed the differences in MMP-2 expressions in low- and high-grade MPNST with tumor's ability to metastasize and the patient's prognosis.

\section{MATERIALS AND METHOD}

This research worked on a descriptive-analytical cross-sectional design and was approved by the Institutional Review Board. This study registered 39 cases, consisting of 19 cases of low-grade MPNST and 20 cases of high-grade MPNST from our hospital from July 2007 to November 2014.

For MMP-2 immunostaining, 4-mm-thick paraffin sections were cut and mounted on poly-L-lysine glass slides. The slides were deparaffinized in xylene and rehydrated with ethanol. Endogenous peroxidase was blocked using $95 \mathrm{ml}$ of methanol plus $5 \mathrm{ml}$ of $3 \%$ hydrogen peroxide solution. Heat-based antigen retrieval was carried out for ten min. Primary antibodies used were from Biocare Medical for MMP-2 (dilution 1:25). Slides were incubated for an hour with the primary antibodies, followed by staining with streptavidin-biotin peroxidase. Slides were then revealed in a diaminobenzidine solution for two min and stained with hematoxylin for five min.

Further, a placenta tissue was used as a positive control for MMP-2. Meanwhile, negative controls were acquired by discarding the primary antibodies. A cut-off point of $>25 \%$ moderate to strong cytoplasmic immunoreactivity on the tumor cells was explained as a positive MMP-2 overexpression. MMP-2 expression was then scored. After that, the correlation between MMP-2 expression and histopathology grading and other clinical variables, such as age, gender, and tumor size and location, were analyzed. The descriptive data were presented in the frequency table. Besides, categorical variables were compared using Chi-square, with the alternative of Fisher's exact test. In this case, $\mathrm{P}<0.05$ was considered statistically significant. Statistical analysis was then executed utilizing SPSS Statistics for Windows, Version 17.0.

\section{RESULTS}

The characteristics of 39 patients were summed up, as presented in Table 1, either overall or according to the histopathological grade. Thirty-nine samples consisted of low-grade $(n=19)$ and high-grade $(n=20)$ MPNST. The number of samples in this study was <50 samples; therefore, to measure the normality 
of data distribution, the Shapiro-Wilk normality analysis was used. If the $p$-value is $>0.05$, the data distribution shows normal.

Five patients (13\%) had disease associated with NF-1 syndrome, and the other 34 patients (87\%) had no association with NF-1 syndrome, with age ranging from 27 until 66 years old. There were two cases for males and three cases for females. Then, high-grade MPNST differentiation was reassessed, and found three cases of rhabdomyoblast differentiation (15\%) of all cases (Fig $2 \mathrm{C}$ ). In addition, lymph node removal was found in four cases, consisting of two low-grade cases and two high-grade cases of MPNST, and there was only one case of metastasis to the lymph nodes with high-grade malignancy (Fig 1A and Fig 2A).

Table 1. The Main Characteristic According to the Histopathological Grade

\begin{tabular}{|c|c|c|c|}
\hline \multirow{2}{*}{ Characteristic } & & \multicolumn{2}{|c|}{ MPNST } \\
\hline & & Low grade & High grade \\
\hline \multirow[t]{2}{*}{ Gender } & Male & $16(84)$ & $12(60)$ \\
\hline & Female & $3(16)$ & $8(40)$ \\
\hline \multirow[t]{2}{*}{ Age } & $<40$ years old & $8(42)$ & $7(35)$ \\
\hline & $\geq 40$ years old & $11(58)$ & $13(65)$ \\
\hline \multirow[t]{3}{*}{ Tumor site } & Extremity & $9(47.4)$ & $6(30)$ \\
\hline & Head and neck & $5(26.3)$ & $8(40)$ \\
\hline & Trunk & $5(26.3)$ & $6(30)$ \\
\hline Size $(\mathrm{cm})$ & & $11.53 \pm 6.8$ & $12.6 \pm 5.6$ \\
\hline \multirow[t]{4}{*}{ Margin status } & Negative & $11(58)$ & $8(40)$ \\
\hline & Positive & $1(5)$ & $4(20)$ \\
\hline & Biopsy & $5(26)$ & $4(20)$ \\
\hline & No data & $2(10)$ & $4(20)$ \\
\hline
\end{tabular}

Moreover, there was an increased MMP-2 expression in twenty-two cases (56.4\%) but not in seventeen cases (43.6\%). At low-grade MPNST (Fig 1C), MMP-2 expression increased in three cases (15.8\%) (Fig 1B), but it did not exist in the other 16 cases (84.2\%) (Fig 1D). Meanwhile, at high-grade MPNST, there were 19 cases (95\%) of increased MMP-2 expression, but it was absent in one case $(5 \%)$.

Furthermore, MMP-2 expression either in male or female patients neither indicated a significant difference ( $p$ 0.083) nor MMP-2 expression in patients aged over or under 40 years old ( $p$ 0.261). The same results were also obtained for MMP-2 expression in extremities, head, neck, and trunk, which did not indicate a significant difference. In addition, a statistical test comparing two unpaired groups, the Fisher test, was employed to measure MMP-2 expression for tumor location, and there was no significance ( $p 0.363$ ). 
Table 2. MMP-2 Expression Concerning the Histopathological Grade and Clinical Variables

MMP-2 expression

\begin{tabular}{llccc}
\cline { 3 - 4 } Characteristic & & $\begin{array}{c}\text { Positive } \\
\mathbf{N}(\%)\end{array}$ & $\begin{array}{c}\text { Negative } \\
\mathbf{N}(\%)\end{array}$ & P-value \\
\cline { 3 - 4 } MPNST & Low grade $(\mathrm{n}=19)$ & $3(15.8)$ & $16(84.2)$ & $0.000^{\mathrm{a}}$ \\
& High grade $(\mathrm{n}=20)$ & $19(95)$ & $1(5)$ & \\
Gender & Male & $14(63.6)$ & $15(36.4)$ & $0.083^{\mathrm{a}}$ \\
& Female & $8(88.2)$ & $2(11.8)$ & \\
Age & $<40$ years old & $7(31.8)$ & $8(47.1)$ & $0.261^{\mathrm{a}}$ \\
& $\geq 40$ years old & $15(68.2)$ & $9(52.9)$ & \\
Tumor site & Extremity & $8(53.3)$ & $7(46.7)$ & $0.363^{\mathrm{b}}$ \\
& Head and neck & $7(53.8)$ & $6(46.2)$ & \\
Size $(\mathrm{cm})$ & Trunk & $7(63.6)$ & $4(36.4)$ & \\
& $\leq 5 \mathrm{~cm}$ & $1(33.3)$ & $2(66.7)$ & $0.884^{\mathrm{a}}$ \\
Total & $>5 \mathrm{~cm}$ & $21(58.3)$ & $15(41.7)$ & \\
\hline
\end{tabular}

$\mathrm{a}=$ unpaired categorical comparative test of Chi-Square

$\mathrm{b}=$ unpaired categorical comparative test of Fisher

Table 2 shows a significant difference between MMP-2 expression at low and high grades at $\mathrm{p} 0.000$. The odds ratio value was 101, and it indicates that the high-grade patients had a possibility (odds) of 101 times to provide positive results for MMP-2 expression compared with low-grade patients (Fig 2B and Fig 2D).

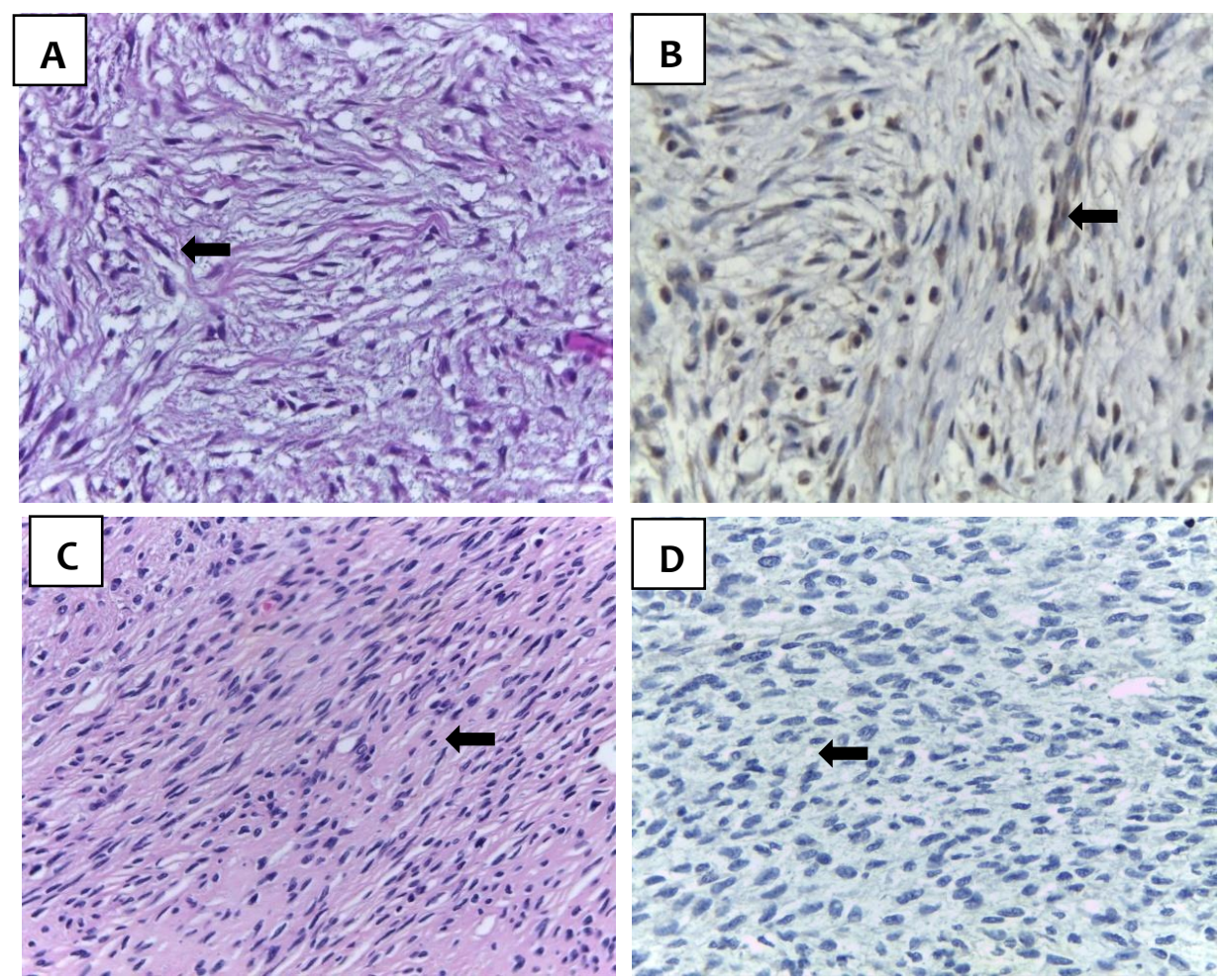

Figure 1. Low-grade MPNST (A, C) HE staining; (B) Focal MMP-2 protein; (D) Negative MMP-2 protein; A, B, C, and D original magnification of 400x 


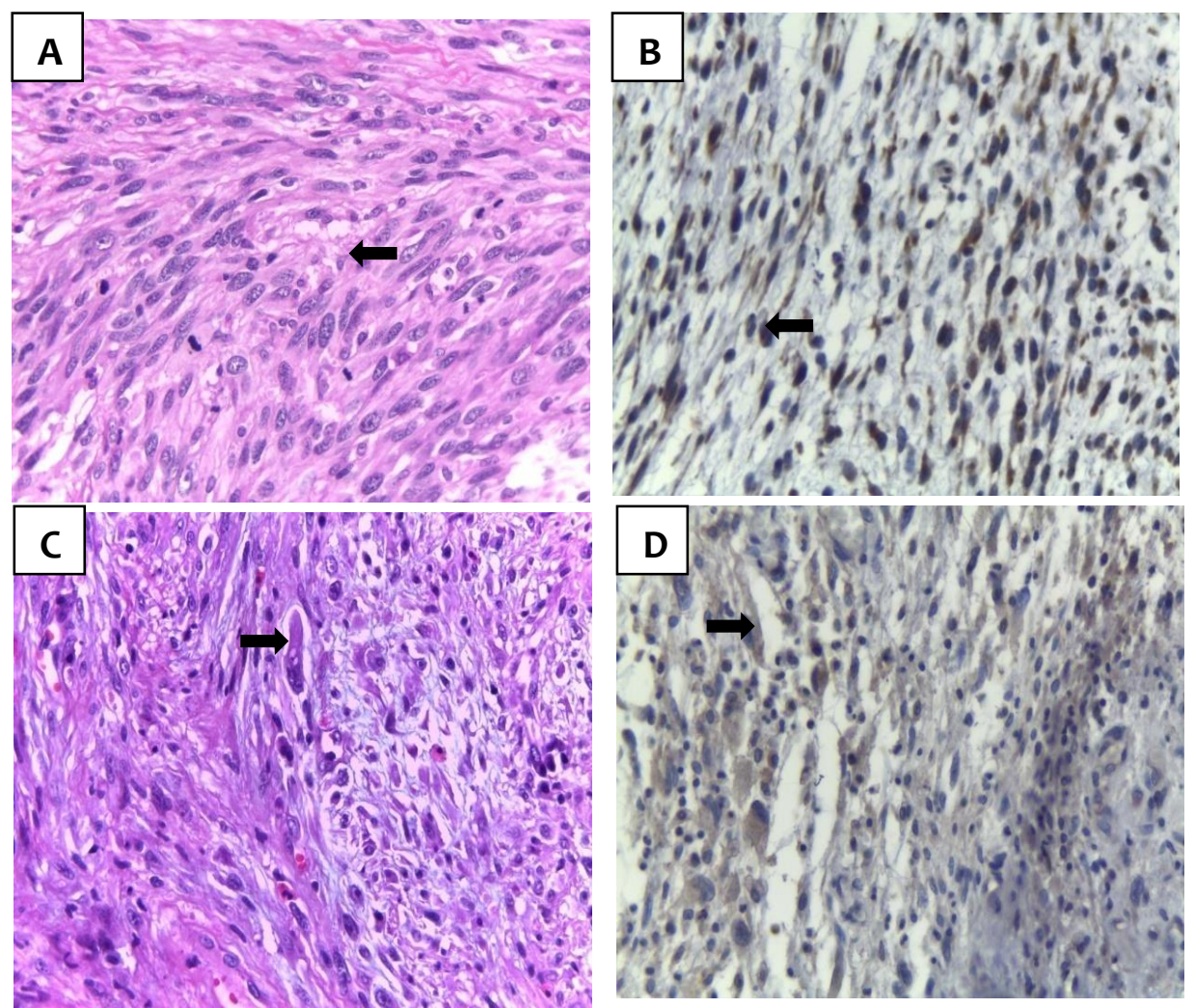

Figure 2. (A) High-grade MPNST, HE staining; (B) Diffuse MMP-2 protein; (C) High-grade MPNST with rhabdomyoblast differentiation, HE staining; (D) Diffuse MMP-2 protein; A, B, C, and D original magnification of 400x

\section{DISCUSSION}

In this study, the ratio of male and female patients was 2.5:1. This data is not in accordance with the literature, which stated that there was no gender preference for MPNST. ${ }^{12}$ However, in the sporadic MPNST cases (de novo), females were more slightly higher than males. ${ }^{13}$ Conversely, the gender ratio in this study is consistent with the study of Schmidt et al, of 35 MPNST cases, there were 27 males (77.1\%) and eight females (22.9\%). It also supports several other studies, which suggested no difference in prognosis between males and females. ${ }^{12}$

The age of patients ranged from 13-66 years, and the majority was in the age of 41-50 years old for 12 cases $(31 \%)$. This data is similar to the literature in which MPNST is usually found in the fourth decade..$^{3-16}$ Concerning this, children rarely suffer from MPNST; however, if there is historical radiation and the presence of NF1, it can also happen in children until young adults. , $^{6,12,17}$

The presence of a historical case of plexiform neurofibroma and NF-1 type is considered a precursor lesion of MPNST. ${ }^{18}$ In this study, we found five cases with NF-1, in which one case was found in low grade and the other four cases in high grade, sized more than $5 \mathrm{~cm}$ for all. Based on the literature, patients with a history of NF-1 have multiple neurofibromatoses, so that the transformation towards malignancy is difficult to identify clinically, and most are high-grade tumors and larger than $5 \mathrm{~cm}$. The presence of NF-1 in patients also increases the risk of metastasis by $15 \%$ compared to the inexistence of NF-1 by $9 \% .{ }^{17}$

In addition, most cases were high-grade malignancies (53.5\%). In this regard, Stucky obtained the same result, in which $61 \%$ of cases were high grades. ${ }^{19} \mathrm{Hence}$, it is crucial to determine the grade of soft tissue tumor because the high-grade tumor has a greater tendency to metastasize than the low-grade tumor, associated with poor prognosis. ${ }^{19-21}$ Likewise, a high-grade MPNST has a 1.8-fold risk of death and a 2 -fold risk of metastasis compared with a low grade..$^{22}$

We also found three cases (7\%) with rhabdomyoblastic differentiation in high-grade MPNST. ${ }^{23}$ Based on the literature study, there are $15 \%$ MPNST differentiation cases, such as rhabdomyoblastic, epithelioid, glandular, osteogenic, and neuroendocrine components, but rhabdomyoblastic is the most common and well known as Malignant Triton Tumor (MTT). In the FNCLCC grading system, MTT is categorized as a high-grade tumor (grade 3). ${ }^{24}$ Besides, in some cytogenetic studies, MTT occurred because of lesions on chromosome 
11 15 and the c-myc gene amplification, leading to acting more aggressive in MTT compared to classic MPNST. ${ }^{14}$

If a tumor is larger than $5 \mathrm{~cm}$, it is increasingly prominent and painful, which should be considered sarcoma. In this study, 36 cases (95\%) were larger than $5 \mathrm{~cm}$. Meanwhile, three cases (16\%) tumors were measured less than $5 \mathrm{~cm}$ and found in low-grade MPNST. Besides, all high-grade tumors (100\%) were larger than $5 \mathrm{~cm}$. The average size of tumors with low-grade malignancy was $11.53 \mathrm{~cm}$, and high-grade malignancy was $12.6 \mathrm{~cm}$. These results are slightly different from Grimer's study, with the average sarcoma size was 10.7 $\mathrm{cm} .{ }^{25}$

According to Grimer, patients with tumors larger than $25 \mathrm{~cm}$ have a risk of death 8.5 times greater than patients with tumors less than $5 \mathrm{~cm}$ at first diagnosed. The larger the tumor size, the worse the prognosis because it is related to local recurrence and distant metastasis, thereby increasing the risk of death. 19,22

Moreover, most of MPNST was located in extremities by $38 \%$, followed by the head and neck by $33 \%$, and in the trunk area by $29 \%$. It aligns with the reference, stating that $45 \%$ of MPNST are located in the extremities, $34 \%$ in the trunk, and $19 \%$ in the head and neck. ${ }^{20}$ In the peripheral areas, extremities have a better survival rate than the central area, such as in the trunk, head, and neck, because the tumor in extremities can be detected earlier and are more convenient for resection. ${ }^{17,22}$

However, tumors in the trunk, head, and neck have a three-fold risk of local recurrence than those in the extremities. It is due to the difficulty of total resection due to its deep location and adjacent to the vital organs in the head and neck. ${ }^{22,26}$ In addition, tumors located in the retroperitoneum, thorax, head, and neck have a low survival rate (15\%) since they tend to be slowly detected so that the tumor has reached a large size and is difficult to excise extensively. ${ }^{26}$ The risk of death increases 2.5 -fold if it is located in the trunk and retroperitoneum. Some cases are also located in rare areas, such as in the prostate, external genitalia, and orbita. Based on the literature, MPNST can occur in all parts of the body containing peripheral nerves. ${ }^{27}$

The data showed a significant difference between the increased MMP-2 expression with a histopathological grade of MPNST. MMP-2 expression increased in high grade than in low grade ( $p 0.000)$. This study supports the reference statement that high-grade tumors showed increased MMP-2 expression compared to low grades. ${ }^{28}$ Besides, two variables for this study, histopathology grading and MMP-2 expression, were strongly related to the odds ratio 101, meaning that MPNST patients with high grades were 101 times more likely to give positive results for MMP-2 expression compared to the low-grade patients.

Based on the literature, high-grade MPNST can metastasize because the MMP-2 protein supports tumor growth, invasion, and metastasis. ${ }^{26}$ Stucky et al. revealed a significant association between high-grade tumors and tumors larger than $5 \mathrm{~cm}$ with a risk of distant metastasis. ${ }^{19}$

Meanwhile, there was no significant correlation between MMP-2 expression on female ( $p$ 0.083), age ( $p$ 0261), tumor size ( $p$ 0.363), and tumor location ( $p$ 0884). Similar results have been reported by Benassi et al., stating a non-significant relationship between MMP-2 expression with the clinical variables of gender, age, and tumor size and location. ${ }^{29}$

In this study, we also found four cases of lymph nodes removal and only one case of lymph node metastasis with high-grade malignancy. In this regard, hematogenous metastasis occurs in the lungs and bones by $65 \%$, while local recurrence occurs in $54 \%$ of cases.

Furthermore, three low-grade MPNSTs showed positive results on MMP-2 staining. This result proves that tumors with low-grade malignancies also have the potential to metastasize, even a bit similar to the research conducted by Benassi et al. that there was one case of low-grade MPNST experiencing metastasis. ${ }^{29}$

One protein that functions in the invasion and metastasis process is MMP-2, usually found in tumors with high-grade malignancies. It supports the results of our study, in which MMP-2 overexpression was found by $95 \%$ in high-grade MPNST. Thus, it can be concluded that the high-grade MPNST had a greater risk of metastasis than low grade. Therefore, identifying potential metastasis with MMP-2 staining is vital to see if the patient has a high risk of metastasis; then, the appropriate treatment for the patient can be decided. ${ }^{29}$

\section{CONCLUSION}

Our study revealed that MMP-2 expression was greater in high-grade MPNST than in low grade, correlated with histopathology grading, but did not correlate with clinical variables, such as gender, age, and tumor size and location. MMP-2 overexpression can be used as a prognostic factor in MPNST development. In addition, MMP-2 expression should be assessed in high-grade MPNST cases to predict metastasis; then, the targeted therapy for the patient may be performed. 


\section{mutiara

\section{CONFLICT OF INTEREST}

We declare that there is no conflict of interest of this paper.

\section{REFERENCES}

1. Kar M, Deo SVS, Shukla NK, Malik A, Gupta SD, Mohanti BK, et al. Malignant Peripheral Nerve Sheath Tumors (MPNST)- Clinicopathological Study and Treatment Outcome of Twenty-four Cases. World J Surg Oncol. 2006; 4: 55. https://doi.org/10.1186/1477-7819-4-55

2. Fletcher CDM, Gronchi A. Tumours of Soft Tissue: Introduction. In: Fletcher CDM, Bridge JA, Hogendoorn PCW, Mertens F, eds. World Health Organization Classification of Tumours of Soft Tissue and Bone. Lyon: IARC; 2013. p.14-8.

3. Srinivas SP, Rao L, Nayak DR. Widely Infiltrating Epiteloid Malignant Peripheral Nerve Sheath Tumors of Skull Base. Malays J Med Sci. 2013; 20: 82-5.

4. Al Gharibi KN. MMP Family Protein Expression as Prognostic Biomarkers in Human Soft Tissue Sarcoma of Extremities [Ph.D. Thesis]. UK: University of Manchester; 2012. [cited 2014 April 9].

5. Koga K, Nabeshima K, Aoki M, Kawakami T, Hamasaki M, Toole BP et al. EMMPRIN in Epitheloid Sarcoma: Expression in Tumor Cell Membrane and Stimulation of MMP-2 Production in Tumor-Associated Fibroblasts. Int J Cancer. 2006; 120; 761-8. https://doi.org/10.1002/ijc.22412

6. Kahari VM, Reunanen N. Matrix Metalloproteinases in Cancer Cell Invasion. In: Kahari VM, Heino J, editors. Cell Invasion. Texas: Eurekah; 2002. p. 1-11.

7. Nagase H, Visse R. Matrix Metalloproteinases and Tissue Inhibitors of Metalloproteinases: Structure, Function and Biochemistry. Circ Res. 2003; 927-39. https://doi.org/10.1161/01.RES.0000070112.80711.3D

8. Nelson AR, Fingleton B, Rothenberg M, Matrisian LM. Matrix Metalloproteinases: Biologic Activity and Clinical Implication. J Clin Oncol. 2000; 18: 1135-49. https://doi.org/0.1200/JCO.2000.18.5.1135

9. Giavazzi R, Garofalo A, Ferri C, Lucchini V, Bone EA, Chari S et al. Batimastat, a synthetic inhibitor of matrix metalloproteinases potentiates the antitumor activity of cisplastin in ovarian carcinoma xenografts. Clinic Cancer Res. 1998:4:985-92.

10. Botos I, Scapozza L, Zhang D, Liotta L, Meyer EF. Batimastat, a Potent Matrix Metalloproteinase Inhibitor, Exhibits an Unexpected Mode of Binding. Proc Natl Acad Sci. 1996: 93: 2749-54. https://doi.org/10.1073/pnas.93.7.2749

11. Hojilla CV, Mohammed FF, Khokha R. Matrix Metalloproteinases and Their Tissue Inhibitors Direct Cell Fate during Cancer Development. Br J Cancer. 2003; 89: 1817-21. https://doi.org/10.1038/sj.bjc.6601327

12. Schmidt RF, Yick F, Boghani Z, Eloy JA, Liu JK. Malignant Peripheral Nerve Sheath Tumors of the Trigeminal Nerve: a Systematic Review of 36 Cases. Neurosurg Focus. 2013; 34.

13. Abdul KFW, Antonescu CU, Dal Cin P, Folpe AL, Geisinger KM, Gown AM, et al. Malignant Tumors of the Peripheral Nerves, in: Weiss SW, Goldblum JR, eds. Soft Tissue Tumors. Mosby: Elsiever; 2008. 903-44.

14. Stasik CJ, Tawfik O. Malignant Peripheral Nerve Sheath Tumor with Rhabdomyosarkomatous Differentiation (Malignant Triton Tumor). Arch Pathol Lab Med. 2006;130: 1878-80. https://doi.org/10.5858/2006-130-1878-MPNSTW

15. Friedrich RE, Hartmann M, Mautner VF. Malignant Peripheral Nerve Sheath Tumors (MPNST) in NF1Affected Children. Anticancer Res. 2007; 27: 1957-60.

16. Fisher C, Montgomery EA, Thway K. Spindle cell sarkomas. In: Epstein JI, eds. Biopsy Interpretation of Soft Tissue Tumors. Wolters Kluwer: Lippincott Williams \& Wilkins; 2011. 195-207.

17. Porter DE, Prasad V, Loster L, Dall GF, Birch R, Grimer RJ. Survival in Malignant Peripheral Nerve Sheath Tumors: a Comparison between Sporadic and Neurofibromatosis Type 1-associated Tumors. Sarcoma. 2009;10.

18. Nielsen G.P, Antonescu C.R, Lothe R.A. Malignant Peripheral Nerve Sheath Tumour. In: Fletcher CDM, Bridge JA, Hogendoorn PCW, Mertens F, eds. World Health Organization Classification of Tumours of Soft Tissue and Bone. Lyon: IARC; 2013. 187-9. https://doi.org/10.1177/1066896917709580

19. Stucky CH, Johnson KN, Gray RJ, Pockaj BA, Ocal IT, Rose PS et al. Malignant Peripheral Nerve Sheath Tumor (MPNST): The Mayo Clinic Experience. Ann Surg Oncol. 2012:19: 878-85. https://doi.org/10.1245/s10434-011-1978-7

20. Abdul KFW, Antonescu CU, Dal Cin P, Folpe AL, Geisinger KM, Gown AM, et al. General Consideration. In: Weiss SW, Goldblum JR, eds. Soft Tissue Tumors. Mosby: Elsevier; 2008.1-14.

21. Alford SH, Vrana MS, Waite L, Heim-Hall J, Sylvia VL, Williams RP. Matrix Metalloproteinase Expression in High Degree Soft Tissue Sarcomas. Oncol Rep. 2003; 18; 1529-36. 
22. Anghileri M, Miceli R, Fiore M, Mariani L, Ferrari A, Mussi C. Malignant Peripheral Nerve Sheath Tumors. Cancer. 2006; 107: 1065-74. https://doi.org/10.1002/cncr.22098

23. Guo A, Liu A, Wei L, Song X. Malignant Peripheral Nerve Sheath Tumors: Differentiation Patterns and Immunohistochemical Features- a Mini Review and Our New Findings. J Cancer. 2012: 3: 303-9. https://doi.org/10.7150/jca.4179

24. Coindre JM. Grading of Soft Tissue Sarcoma: Review and Update. Arch Pathol Lab Med. 2006: 130: 1448-53. https://doi.org/10.5858/2006-130-1448-GOSTSR

25. Grimer RJ. Size Matters for Sarcomas. Ann $R$ Coll Surg Engl; 2006: 88: 519-24. https://doi.org/10.1308/003588406X130651

26. Minovi A, Basten O, Hunter B, Draf W, Bockmuhl U. Malignant Peripheral Nerve Sheath Tumors of the Head and Neck: Management of 10 Cases and Literature Review. Wiley Periodicals, Inc. Head Neck. 2006; 29: 439-45. https://doi.org/10.1002/hed.20537

27. Benassi MS, Gamberi G, Magagnoli G, Molendini L, Ragazzini P, Merli M, et al. Metalloproteinase Expression and Prognosis in Soft Tissue Sarcomas. Ann Oncol. 2001; 75-80. https://doi.org/10.1023/a:1008318614461

28. Aydin MD, Yildirim U, Gundogdu C, Dursun O, Uysul HH, Ozdikici M. Malignant Peripheral Nerve Sheath Tumor of the Orbit: Case Report and Literature Review. Skull Base. 2004;14:109-13. https://doi.org/10.1055/s-2004-828705

29. Yang HK, Jeong KC, Kim YK, Jung SK. Role of Matrix Metalloproteinases (MMP)2 and MMP-9 in Soft Tissue Sarcoma. Clinic Orthoped Surg. 2014; 6: 443-54. https://doi.org/10.4055/cios.2014.6.4.443 